\title{
8. Global precarity chains and the economic impact on Cambodia's garment workers
}

Katherine Brickell, Theavy Chhom, Sabina Lawreniuk, and Hengvotey So

In the first year of the COVID-I9 pandemic, Cambodia's emergency health response was widely heralded by the international community as a success (Heng 2020; Hyder and Ly 2020; Ratcliffe 2020). As of January 202I, the country had recorded only 460 COVID-I9 cases and zero deaths. Yet its achievements in mitigating the worst health impacts of the pandemic during this period did not insulate its population of 16 million people from the economic fallout wrought by COVID-I9. Far from it: Cambodia's deep integration into and reliance upon the faltering global market left at least I.76 million jobs at risk (World Bank 2020) in Cambodia's three most important economic sectors: garments, tourism, and construction.

In this chapter, we focus attention on Cambodia's garment industry, which prior to the pandemic had a large and highly feminised labour force, nearing one million workers, $80 \%$ of whom were women (ILO 20I8). We present an analysis of the economic impact of COVID-I9 on workers from January 2020, when the pandemic first took hold in China, up until February 202I. Drawing on original research from our UKRI GCRF-funded ReFashion study (www.ReFashionStudy.org), we understand and contextualise the data on workers' experiences within the broader debate surrounding global value chains, and we advance the idea of global precarity chains.

Global value chains bring attention to links and relationships between different sectors along the chain of production, including 'all aspects of the process of production, distribution and retailing across global supply networks' (Barrientos 200I, p.83). Mainstream thinking in academic and policy circles has represented these chains as conducive to new development opportunities for firms and regions in the global South

How to cite this book chapter:

Brickell, Katherine; Chhom, Theavy; Lawreniuk, Sabina; and So, Hengvotey. 2022. 'Global precarity chains and the economic impact on Cambodia's garment workers'. In: Shin, Hyun Bang; Mckenzie, Murray; and Oh, Do Young (eds) COVID-I9 in Southeast Asia: Insights for a post-pandemic world. London: LSE Press, pp. 97-I07. DOI: https://doi.org/I0.3I389/lsepress.cov.h License: CC BY 4.०. 
(Selwyn 20I9). However, there exists considerable empirical evidence that these global value chains adversely 'generate new forms of worker poverty' (Selwyn 2019, p.7I) for those undertaking the 'nimble finger' work of garment production (Elson and Pearson I98I). Bolstering export-oriented growth, women in the global South have been enrolled in labour-intensive patterns of low-skilled and low-paid garment work that is associated with casualisation, excessive hours, and weak social protection (Nadvi 2004). Under these conditions, women workers 'effectively provide a subsidy to production under supply chains and pay the price of government strategies that rely on precarious jobs' (Kidder and Raworth 2004, p.I3).

Precarious jobs are generally understood as those which are insecure, dangerous, and/or characterised by poor working conditions and pay. Capitalism 'works to divide and differentiate populations' (Bhattacharyya 20I8, p.I47), leading certain individuals and groups to 'suffer from failing social and economic networks of support and become differentially exposed to injury, violence, and death' (Butler 2009, p.25). In this chapter we show the significance of what we call 'global precarity chains' for understanding lived experiences of workers in (pre-)COVID-I9 times. It begins with a contextual reading of Cambodia's development trajectory vis-à-vis the garment industry, before turning to two workers' experiences of navigating this political economy during the first year of the COVID-I9 pandemic. The chapter evidences, first, the precarious location of Cambodia's garment industry in the value chain and its long-term exposure to shocks like the pandemic; second, the dependency on debt that evolved in response to precarious work in the industry prior to COVID-I9 but escalated during the pandemic among poorly paid, suspended, and terminated garment workers; and, third, the precarious nature of development more widely in Cambodia, epitomised by the struggle to diversify economically and create alternative livelihoods outside the garment industry. These were significant issues that predated the pandemic and extended beyond its bounds, calling into further question the ability of Cambodia's elected development pathway to create decent work for all through integration into volatile and exploitative global precarity chains.

\section{Precarious development in Cambodia}

It is by now almost a truism to attribute the 'miracle' (World Bank 2018) of Cambodia's transition to the heady growth of its garment 
manufacturing sector, catalysing a remarkable three-decade turnaround from post-conflict state to 'Asia's new tiger economy' (ADB 20I6). It is easy to overlook that this take-off occurred as much by accident as design: a feat of industrial serendipity rather than strategy, as Cambodia's re-entry to the global marketplace in the mid-I990s coincided with regional volatility in the wider garment supply chain. Here, the 'business-friendly investment regime' (Bargawi 2005, p.5) pursued by the Cambodian government following the signing of the Paris Peace Accords in I99I caught the eye of other Asian garment exporters, whose growth at the time was impeded by quotas restricting access to the US market. Preferential trade access bestowed on Cambodia, first by the US in 1997 and then by the EU in $200 \mathrm{I}$, accelerated the reshoring of garment production from original East Asian outsourcing hubs to these new frontiers in a neat spatial fix for manufacturers. Where, in 1995 , Cambodia had 20 factories, employing I 8,000 workers and generating exports worth US\$27 million (Bargawi 2005, p.9), in 201 8 there were more than 600 , with a workforce nearing I million, generating a combined export value of US\$8 billion annually (ILO 20I 8).

For much of the intervening period, Cambodia's economy outpaced other post-conflict societies globally (Hill and Menon 20I4), with IO years of GDP growth averaging double-digit figures to 2008 and securing graduation to lower-middle-income status in 2015. Over a similar timeframe, the national poverty rate fell dramatically, from $47.8 \%$ in 2007 to $13.5 \%$ in 2014 (World Bank 20I7, p.I2). It has been hard to refute the unbridled optimism of initial accounts of the industry's success in pioneering Cambodia's development. Early analyses hailed the 'wonderful job opportunity' (Yamagata 2006, p.3) the sector afforded to women, their labour steering a 'blistering' (World Bank 20I7, p.43) trajectory emulating historical precedent, where 'the textile and apparel industries have led industrialization at the early stage of development in many countries of the world' (Yamagata 2006, p.4).

Voices from the factory floor, however, offer a competing narrative that challenges the industry's developmental credentials. As further trade liberalisation fostered increasing international competition in an already densely crowded garments market, downwards pressure on unit prices has been exacted on industry profits. Where forecasters have long divined that such falls 'should be readily absorbable by Cambodian exporters' (Bargawi 2005), in practice it is workers who have borne cuts to balance to the books. Between 200I and 20II, as GDP growth and consumer inflation soared, real wages in the sector fell by $22 \%$, locked 
in at rates below reproduction requirements (Selwyn 2019). A spontaneous eruption of mass labour unrest at the end of 2013 evidenced the scale of mounting discontent. Dispelled with lethal violence by state security forces, the prospect of further collective action has since been thwarted by 'authoritarian innovations' (Ford, Gillan, and Ward 2020) in labour governance that stymie and criminalise the organisation of independent trade union activity. Flexibilisation and intensification of work patterns resulted, with employers resorting to the increasing use of three- and six-month fixed-duration contracts and escalating production targets to extract ever greater margins from an increasingly exploited workforce (Human Rights Watch 2015).

Yet, beyond GDP growth and job creation, it is not clear how the industry has contributed to wider national development objectives. Cambodian manufacturing remains stubbornly located at the 'downstream, mass market' (Bargawi 2005, p.5) section of the garment value chain, focused on so-called 'cut-make-trim' operations that turn readymade fabrics and fibres into packaged products, shipped ready to hang on retail shelves. It is an activity where the share of value added to the final output is already relatively low, further reduced by reliance on imports for inputs like textiles, threads, and trimmings. The Cambodian government's business-friendly policies including tax breaks for imports and tax holidays for new firms lured investment but permitted the industry to get away with injecting little cash into the coffers of the national budget in return. Unlike Cambodia's competitors in the sector, such as Bangladesh, there is no protection for domestic firms. The resulting high proportion of foreign ownership, hovering around $90 \%$ since the I990s, means that 'a significant part of the profits are repatriated' (Ear 2013, p.93).

As the garment sector has grown to dominate Cambodia's share of employment and exports, its shallow integration and weak contribution to the national economy have prompted repeated calls to develop and diversify beyond cut-make-trim manufacturing, incorporating higher-value-added segments or sectors (World Bank 20I7). Yet the continued growth of garments, rebounding even following the 2008 crash, provided little incentive to work at levelling up. As such, repeated warnings went unheeded. Heading into 2020 , then, Cambodia's post-conflict recovery resembled a paper tiger: GDP and jobs had yielded only a 'mirage of development' (Crossa and Ebner 2020, p.I218), shielding a precariously lopsided and trade-dependent economy and seeming particularly prone to external crisis. 


\section{Precarious work and precarious debt}

COVID-I9 provided this long-anticipated shock, and its impacts exposed the precarious foundations of development in Cambodia. The global garment industry was severely impacted by the pandemic. Cambodia's precarious location within the wider supply chain brought sustained damage from different waves of the outbreak (Lawreniuk 2020). First came upstream delays of raw material delivery due to manufacturing disruptions in China. Then, dramatic falls in demand from consumer lockdowns in Europe and the US led to the subsequent cancellation of orders by international retailers. The consequence of this was the temporary suspension or firing of garment workers in factories where production was interrupted or permanently ceased, with more than Ioo factories closed. The ramifications of this situation were acute for women in Cambodia. Outside the agriculture sector, there was a pronounced segregation of occupations by sex, with women in a narrow range of traditional 'female' occupations, including trade, crafts, sewing, and the entertainment industry (UNIFEM et al. 2004, p.43). Women remained under-represented in managerial and technical roles in the country (ILO 2020), and there were high levels of inequality in higher education attainment (UNDP 20I9). Cambodia's precarious development therefore left garment factory workers with few options to make a viable living outside the garment industry, whose legacies of precarious work rendered day-to-day existence a challenge even for those who were able to return to work.

This acute lack of alternatives to garment work and markedness of gender inequality in Cambodia are evident in garment worker Lida's experiences of the gendered burdens of managing household finances. ${ }^{\mathrm{I}}$ Lida had been married since 2008 and began factory work soon after. After three years, the couple had their first baby, and she moved to live with her mother-in-law because of childcare needs. At this time, her son had an allergy to powdered milk, and she stopped working to breastfeed him. Several years later, Lida started searching and applying for a job at a garment factory to make ends meet. She struggled juggling factory work and childcare. Furthermore, her husband failed to contribute any of his salary to support the family. COVID-I9 led to Lida's suspension from her garment job for several months at the end of 2020 . During the suspension, she received US $\$ 40$ per month from a government support fund and US\$30 per month from the factory. In 202I, the situation only worsened: 
The factory announced that they had cancelled product orders; therefore, they don't have much work for all workers. They decided to change the shift patterns, meaning that I can only work between Io to I 4 days for the whole of January. At the same time, the factory opened up job announcements for new workers. I don't understand ... I always think of finding another job, but I don't have any ability or capacity. I think that I can sell vegetables in the village or at the market, but I don't have any support from my husband, so it is not easy to do. I can only dream, but I can't find a way to follow my dream.

The reduction in working hours put Lida in a precarious financial position, and the factory's decision to hire new workers made her feel discriminated against. Her teammates made complaints about her slow work rate on the normally fast-paced production line. Other workers began to resent her lack of ability, as it placed a further burden on them to work harder and compensate in order to reach production targets. At the same time, Lida felt compelled to accept these conditions given the lack of alternative options. The consequences of completely losing her garment job therefore weighed upon her heavily:

Nowadays, I feel like I am a single mother. I need to handle all my family burdens and support my two children. I am so depressed about this. I am afraid to lose my job because if I lost my job, I will have no money to support my family. I seem to have mental health problems ... I keep thinking all night about these worries.

Lida's experiences of anxiety and depression were shared more widely among garment workers and, for many women, were exacerbated by the burdens of debt they were carrying. This was the case for Chantou, who was orphaned at an early age. In 201 8, 58-year-old Chantou had taken out a bank loan of US\$6,000 to pay for her disabled sister's healthcare costs in her rural homeland. Although garment workers pay into a contributory health insurance scheme, their dependents are not covered. The garment sector's limited contributions to the national budget, despite its contribution to record GDP growth, had stalled the development of wider healthcare provision and other social protections. Healthcare costs expended by family members could be financially ruinous for workers. Prior to her May 2020 suspension, Chantou had been paying US\$ I 50 from her US\$2 30 salary as a factory security guard to repay the outstanding US\$4,000 loan. Once suspended, her source of repayment dried up:

I begged them not to suspend me. I begged them for work because I had no money to repay the loan. They did not agree ... I had no money to pay the 
private loans ... I was screaming and crying loudly. I have endured hunger. I am having to endure eating salt and fermented fish until I have a full salary ... I borrowed more money from the money lenders for four months consecutively, and my monthly borrowing was US\$100, combined with cash support of US\$70 per month from the factory and the Ministry to repay the private loan.

Chantou's account illuminates the pandemic's toll on garment workers whose lives were trapped by a downward cycle of debt commitments, where they were forced to take out new loans with higher interest rates to repay existing debts. While Chantou returned to work after four months, she encountered partial and irregular payments of her wages, which again made loan repayments difficult. She held a deep-seated fear that she would soon lose the residential land she had secured as collateral for the loan.

COVID-I9's economic impact, then, was not only limited to income loss; it also entrenched households' growing reliance on debt to finance everyday consumption and survival. The lack of affordable healthcare in Cambodia is a key structural reason for reliance on credit (Van Damme et al. 2004). Rather than improving people's developmental prospects through driving entrepreneurship, microfinance loans are typically used for daily expenditures on household costs (Bylander 20I4; Bylander 20I5). This reliance on debt to smooth immediate needs is, as Selwyn (2019) has expounded, a longer-term product of the industry's super-exploitation of workers, where wage rates fail to meet basic reproduction requirements. As Brickell et al. (2020, p.2) have explained, even:

prior to the pandemic, the microfinance sector's expansion in Cambodia temporarily papered over gaps in public service provision experienced strongly in rural areas, where liquidity was used to deal with household cash-flow uncertainties linked to education, health, and food.

As a result, the economic fallout of the COVID-I9 pandemic was a major risk to borrowers, the majority of whom, like Chantou, were reliant on labour wages to repay loans (Green and Estes 2019). Media coverage in Cambodia suggests that the sacrifices that Chantou was making to repay the debts were not unusual. As journalist Gerald Flynn (2020) has written, 'debts to MFIs [microfinance institutions] are a more immediate threat than the virus', with workers facing a decision between eating or repaying loans.

Although microfinance loans assist workers like Chantou in the short term, the long-term burden of newly acquired loans from the COVID-I9 shutdowns, on top of existing ones, would only aggravate 
over-indebtedness and the severity of sacrifices needed to repay them. The World Health Organization (202I), for example, expressed concern that the economic impact of COVID-I9 would worsen inequalities and fuel malnutrition for billions in Asia. These inequalities are intensely gendered; the pressures of COVID-I9 in Cambodia manifested in precarities tied to women's predominant status in the garment industry and as household managers responsible for social reproduction.

\section{Conclusion: from paper tiger to papering over the cracks}

In this chapter, we have introduced the experiences of two Cambodian workers grappling with the economic consequences of the pandemic on a global garment industry in turmoil. The most severe hardships presented by COVID-I9 fell on workers inhabiting the most vulnerable positions in the global value chain. To try to cope amid a global crisis, garment workers in Cambodia turned to credit borrowing to paper over the cracks and meet urgent survival needs. In doing so, their fates became intimately connected with the global financial institutions seeking a high return from the unfettered growth of Cambodia's microfinance sector (Bateman 20I7). Garment workers' lives are, more than ever, embedded within cross-cutting global precarity chains tied to the manufacturing and finance sectors. Their experiences underscore, first, the vulnerability of the Cambodian economy given its reliance on export earnings coming from the garment sector and, second, that, if decent work for all is to have any hope of being possible in practice, then the country needs to address its structural gender inequalities, which hinder women's educational and career progress outside the garment industry. The COVID-I9 pandemic did not make value chains newly precarious but rather exposed and compounded long-standing vulnerabilities that women had already been confronting on a daily basis years before its devastating arrival.

\section{Note}

I. All names of garment workers in this chapter are pseudonyms. Their stories arise from 60 semi-structured interviews we conducted with workers between January and February 202I. Given this, the chapter reflects on the indirect economic impacts of the pandemic, as experienced through the first year of the crisis. All worker interviews were conducted in Khmer by Cambodian members of the research team and later transcribed into English. They were recruited to participate in the study with the assistance of independent labour unions and the Ministry of Labor in Cambodia. 


\section{Acknowledgements}

We are grateful to the garment workers who participated in our ReFashion study in Cambodia. The research was funded by UKRI GCRF (EP/Vo26054/I). Access requests to underlying research materials should be addressed to rdm@ royalholloway.ac.uk.

\section{References}

Asian Development Bank. (2016). Here Comes Cambodia: Asia's New Tiger Economy. https://perma.cc/KZT9-MEJE [Last accessed 3 February 202 I].

Bargawi, Omar. (2005). Cambodia's Garment Industry: Origins and Future Prospects. UK: Overseas Development Institute. https://perma.cc/ $\mathrm{C}_{3} \mathrm{MH}$ -PBT6 [Last accessed 26 May 202I].

Barrientos, Stephanie. (200I). 'Gender, flexibility and global value chains'. IDS Bulletin,vol.32,no.3,pp. 83-93.https://doi.org/IO.I I I I/j.I759-5436.200I. mp32003009.x

Bateman, Milford. (2017). The Rise of Cambodia's Microcredit Sector: An Unfolding Calamity. European Association of Development Research and Training Institutes General Conference, Bergen, 2I-23 August 2017.

Bhattacharyya, Gargi. (2018). Rethinking Racial Capitalism: Questions of Reproduction and Survival. UK: Rowman and Littlefield.

Brickell, Katherine; Picchioni, Fiorella; Natarajan, Nithya; Guermond, Vincent; Parsons, Laurie; Zanello, Giacomo; and Bateman, Milford. (2020). 'Compounding crises of social reproduction: Microfinance, over-indebtedness and the COVID-I9 pandemic'. World Development, vol. I36, pp. I-4. https://doi.org/IO.IOI6/j.worlddev.2020.105087

Butler, Judith. (2009). Frames of War: When is Life Grievable? UK: Verso.

Bylander, Maryann. (20I4). 'Borrowing across borders: Migration and microcredit in rural Cambodia'. Development and Change, vol. 45, no. 2, pp. 284-307. https://doi.org/IO.I I I I/dech.I 2080

Bylander, Maryann. (2015). 'Depending on the sky: Environmental distress, migration, and coping in rural Cambodia'. International Migration, vol. 53, no. 5, pp. I 3 5-I 47. https://doi.org/IO.I I I I/imig. I 2087

Crossa, Mateo; and Ebner, Nina. (2020). 'Automotive global value chains in Mexico: A mirage of development?' Third World Quarterly, vol. 4I, no. 7, pp. I2I 8-I239. https://doi.org/IO.IO80/OI436597.2020.I76I 252

Ear, Sophal. (2013). 'Cambodia's garment industry: A case study in governance'. Journal of Southeast Asian Economies, vol. 30, no. I, pp. 9I-IO5. https://doi.org/IO.I355/ae30-lf 
Elson, Diane; and Pearson, Ruth. (I98I). "“Nimble fingers make cheap workers": An analysis of women's employment in Third World export manufacturing'. Feminist Review, vol. 7, no. I, pp. 87-107. https://doi.org/I0.1057 /fr. I98 I.6

Flynn, Gerald. (2020). 'Garment workers cornered by job loss, virus fears and looming debt’. VOD, I6 April. https://perma.cc/SLG3-47JC [Last accessed 3 February 202I].

Ford, Michele; Gillan, Micheel; and Ward, Kristy. (2020). 'Authoritarian innovations in labor governance: The case of Cambodia'. Governance (pre-print). https://doi.org/IO.I I I I/gove.I 2559

Green, Nathan; and Estes, Jennifer. (2019). 'Precarious debt: Microfinance subjects and intergenerational dependency in Cambodia'. Antipode, vol. 5 I, no. I, pp. I 29-I 47. https://doi.org/IO.I I I I/anti. I 24 I 3

Heng, Kimkong. (2020). 'What lies behind Cambodia's surprise coronavirus success?' Nikkei Asia, 2 June. https://perma.cc/EZB5-W853 [Last accessed 3 February 202I].

Hill, Hal; and Menon, Jayant. (20I4). 'Cambodia: Rapid growth in an open, post-conflict economy'. The World Economy, vol. 37, no. I2, pp. I649I 668. https://doi.org/Io. I I I I/twec. I 2206

Human Rights Watch. (2015). 'Work Faster or Get Out': Labour Rights Abuses in Cambodia's Garment Industry. USA: Human Rights Watch. https://perma.cc/LG6S-2SJD [Last accessed 26 May 202I].

Hyder, Ziauddin; and Ly, Nareth. (2020). 'What explains Cambodia's effective emergency health response to Covid-I9?' World Bank Blogs, I9 November. https://perma.cc/GMV3-XXMF [Last accessed 3 February 202I].

International Labour Organization. (2018). Living Conditions of Garment and Footwear Sector Workers in Cambodia. Switzerland: International Labour Organization Cambodia Garment and Footwear Sector Bulletin Issue 8. https://perma.cc/J2DM-3 ERZ [Last accessed 3 February 202I].

International Labour Organization and Organisation for Economic Cooperation and Development. (2020). Social Dialogue, Skills and COVID-I9. Switzerland: International Labour Organization. https://perma.cc/E $35 \mathrm{~J}$ -SC 3 X [Last accessed 3 April 202I].

Kidder, Thalia; and Raworth, Kate. (2004). "Good jobs” and hidden costs: Women workers documenting the price of precarious employment'. Gender and Development, vol. I2, no. 2, pp. I2-2 I. https://doi.org/Io.Io80/I 355 20704 I 233 I332I 50

Lawreniuk, Sabina. (2020). 'Necrocapitalist networks: COVID-I9 and the "dark side" of economic geography'. Dialogues in Human Geography, vol. IO, no. 2, pp. I99-202. https://doi.org/IO.I I 77/2043820620934927 
Nadvi, Khalid. (2004). 'Globalisation and poverty: How can global value chain research inform the policy debate?' IDS Bulletin, 35, pp. 20-30. https://doi .org/IO.I I I I/j.I 759-5436.2004.tbooI05.x

Ratcliffe, Rebecca. (2020). 'How have Thailand and Cambodia kept Covid cases so low?' The Guardian, I 6 December. https://perma.cc/Q24E-DFND [Last accessed I 2 February 202I].

Selwyn, Benjamin. (2019). 'Poverty chains and global capitalism'. Competition and Change, vol. 23, no. I, pp. 7I-97. https://doi.org/IO.II77/IO2452 $94 \mathrm{I} 8809067$

United Nations Development Programme. (2019). Human Development Report 2019. USA: United Nations Development Programme. https://perma .cc/673 M-VJCZ [Last accessed I 2 February 202I].

United Nations Development Fund for Women (UNIFEM); World Bank; Asian Development Bank; United Nations Development Programme; and Department for International Development of the United Kingdom. (2004). A Fair Share for Women: Cambodia Gender Assessment. Cambodia: United Nations Development Fund for Women. https://perma.cc/8ZZ $5-2 \mathrm{CZB}$ [Last accessed 26 May 202I].

Van Damme, Wim; Van Leemput, Luc; Por, Ir; Hardeman, Wim; and Meessen, Bruno. (2004). 'Out-of-pocket health expenditure and debt in poor households: Evidencefrom Cambodia'.TropicalMedicine and InternationalHealth, vol. 9, no. 2, pp. 273-280. https://IO.I046/j.I365-3 I 56.2003.0 I I94.X

World Bank. (2017). Cambodia - Sustaining Strong Growth for the Benefit of All. USA: World Bank. https://perma.cc/WBM8-9PBQ [Last accessed I 2 February 202I].

World Bank. (2018). Riding the Wave: An East Asian Miracle for the 2 Ist Century. USA: World Bank. https://perma.cc/V 55 Y-ZYE 3 [Last accessed I 6 May 202I].

World Bank. (2020). Cambodia Economic Update: Cambodia in the time of COVID-I 9. USA: World Bank. https://perma.cc/E 3 RM-VWX 3 [Last accessed I 2 February 202I].

World Health Organization. (202I). UN Agencies Warn Economic Impact of COVID-I9 and Worsening Inequalities Will Fuel Malnutrition for Billions in Asia and the Pacific. https://perma.cc/F5RN-MDFD [Last accessed I 2 April 202I].

Yamagata, Tatsufumi. (2006). 'The Garment Industry in Cambodia: Its Role in Poverty Reduction through Export-Oriented Development'. Cambodian Economic Review, vol. 2, pp. 8 I-I36. 